\title{
DISCLAIMER
}

This report was prepared as an account of work sponsored by an agency of the United States Government. Neither the United States Government nor any agency thereof, nor any of their employees, makes any warranty, express or implied, or assumes any legal liability or responsibility for the accuracy, completeness, or usefulness of any information, apparatus, product, or process disclosed, or represents that its use would not infringe privately owned rights. Reference herein to any specific commercial product, process, or service by trade name, trademark, manufacturer, or otherwise does not necessarily constitute or imply its endorsement, recommendation, or favoring by the United States Government or any agency thereof. The views and opinions of authors expressed herein do not necessarily state or reflect those of the United States Government or any agency thereof.

\section{Potentiometric Studies at ORNL with Hydrogen Electrode Concentration Cells}

\author{
R. E. Mesmer, D. A. Palmer, and D. J. Wesolowski \\ Chemical and Analytical Sciences Division \\ Oak Ridge National Laboratory \\ Oak Ridge, TN 37831
}

\begin{abstract}
A description of hydrogen electrode concentration cells developed in the late sixties and currently in use at Oak Ridge is given. The method of measurement, data interpretation, and published results are reviewed for studies of acid-base ionization, metal ion hydrolysis, and metal complexation reactions using principally such cells in titration or flow modes.
\end{abstract}

\section{INTRODUCTION}

Measurement of the hydrogen ion concentration or activity is important for the description of many chemical equilibria in aqueous chemistry because of the central involvement of $\mathrm{H}^{+}$ions in reactions promoted by the amphoteric character of the water itself. Electrochemical measurements have been the most accurate and commonly used method for such measurements because of the availability principally of glass and hydrogen electrodes. It has been known for a long time that use of glass electrodes is limited to $0-150^{\circ} \mathrm{C}$ but Lietzke and his coworkers (cited in ref. 1) demonstrated the excellent performance of hydrogen electrodes at temperatures to at least $200^{\circ} \mathrm{C}$. Lietzke and his coworkers studied a series of $H X-M X_{n}$ electrolyte mixtures in cells with hydrogen electrodes combined with silver-silver chloride reference electrodes. In the combination with in situ $\mathrm{Ag} / \mathrm{AgCl}$ electrodes the highest precision was limited to about $200^{\circ} \mathrm{C}$ because of complications from the reduction of $\mathrm{AgCl}$. The absence of suitably stable reference electrodes for and to $300^{\circ} \mathrm{C}$ (Lietzke, 1973) led us to develop hydrogen electrode concentration cells for studies of equilibria of interest in reactor and steam generator systems to about $300^{\circ} \mathrm{C}$ during the late 1960 's and seventies. [2] The first such cell (Mesmer et al., 1970) was described in 1970 for measurements of the ionproduct of water in $1 \mathrm{~m} \mathrm{KCl}$ to $295^{\circ} \mathrm{C}$. [3] Soon thereafter (Sweeton, et al., 1971) a flow-cell without a vapor phase was reported and later used for a number of important volatile buffer systems. [4] During the intervening two dozen years over twenty scientists have participated in potentiometric studies at Oak Ridge and much of that work will be summarized in this paper. The very high precision and ease of operation make these cells appropriate for much the same applications in solution chemistry to $300^{\circ} \mathrm{C}$ as glass electrodes have been at near ambient conditions. 


\section{DISCLAIMER}

Portions of this document may be illegible in electronic image products. Images are produced from the best available original document. 


\section{HYDROGEN ELECTRODE CONCENTRATION CELLS}

\section{Experimental Apparatus and Procedures}

Because of space limitations here we will devote this description solely to the titration cell shown in Figure 1(a), but the same general principles apply to the flow-cell with the exception of a high impedance channel in that cell to isolate the metal vessel from the electrochemical cell solution. The pressure vessel was machined of Haselloy B, chosen for its resistance to corrosion especially stress-cracking in the presence of chloride and to hydrogen embrittlement. Two concentric internal compartments are machined from Teflon with volumes of about $125 \mathrm{ml}$ and $30 \mathrm{ml}$, respectively. The smaller or inner compartment contains a reference solution with the acidity or basicity fixed by a known amount of a strong acid or strong base. A small hole near the top of the inner cup assures $\mathrm{H}_{2}$ pressure equalization while limiting the vapor transfer. Electrical contact is made through a small porous plug of Teflon compressed in a hole in the bottom of the reference compartment. The leak-rate is adjusted by compressing the plug to give a flow-rate less than $1 \mathrm{mg} /\left(\mathrm{cm}\right.$ of $\mathrm{H}_{2} \mathrm{O}$ head) per hour at ambient conditions. Titrations are conducted by injection of a titrant from a calibrated pressure generator fabricated from Zircoloy-2. The titrant is transmitted through Peek or platinum lines and valves for experiments in which composition variation is advantageous.

\section{Cell Potentials and Data Analysis}

Electrochemical cells with glass and hydrogen electrodes for sensing hydrogen ions in aqueous solutions are generally used with reference electrodes near ambient conditions. If, as is the custom however, the reference electrode is separated from the test solution by a bridge solution (i.e., liquid junction is present) then the nature of the reference solution makes no difference. Also, these cells have similar limitations as concentration cells. Hydrogen electrode concentrations cells have been the workhorse for studies at high temperatures principally at Oak Ridge for nearly twenty-five years because of the excellent response and stability of hydrogen electrodes.

The cell representation for a hydrogen electrode concentration cell is given below for the study of the ionization of a weak acid, HA,

$$
H_{2}, P t\left|m_{H C l}, m_{N a C l} \| m_{H A}, m_{N a A}, m_{N a C l}\right| P t, H_{2}
$$

Here the molality of $\mathrm{NaCl}$, present as a supporting, non-complexing electrolyte, is high compared to the other solutes, e.g., $\mathrm{m}_{\mathrm{NaC} /} / \mathrm{m}_{\mathrm{HCl}} \sim \mathrm{m}_{\mathrm{NaCl}} / \mathrm{m}_{\mathrm{NaA}} \sim 100$ and consequently, the activity coefficient of the minor components can be assumed to be equal in the two compartments, while the liquid junction potential is minimized and is calculable by the Henderson equation. $[1,5]$ The cell potential is given by

$$
\Delta E=R T / F \cdot \ln \left(\left[H^{+}\right], /\left[H^{+}\right]\right)+E_{L}
$$

The $\gamma_{\mathrm{H}^{+}}$in the two compartments are equal, the bracketed terms represent molalities, and $E_{L J}$ represents the liquid junction potential estimated using limiting conductances for the ions. For the special case of small differences in ion concentrations for the two solutions the logarithm term of the Henderson equation is linearized and there is a term in the sum for each ion present and the liquid junction potential is

$$
E_{L J}=\sum D_{i}\left([i]-[i]_{r}\right)
$$


$D_{1}$ is given by

$$
D_{i}=R T / F \cdot Z_{i} \lambda_{i} /\left|Z_{i}\right| \sum\left|Z_{i}\right| \lambda_{i}[i]
$$

where $Z_{i}$ is the charge on the ion and $\lambda$ is the limiting conductance. Because of the high mobility of $\mathrm{H}^{+}$and $\mathrm{OH}^{-}$, the terms involving these ions usually make the greatest contribution to $E_{L J}$. The magnitude of the calculated liquid junction potential is generally accurate to $15-20 \%$ [5] and this contributes little error when $E_{L J}$ is kept to $<1$ or $2 \mathrm{mV}$. The magnitude of the liquid junction potential introduced by replacement of $1 \%$ of the $\mathrm{Na}^{+}$by $\mathrm{H}^{+}$as a function of temperature is shown in Figure 1(b) along with the \% error in $\mathrm{H}^{+}$concentration represented by ignoring that potential. [1]

The observed ligand number (or average number of ligands per metal ion in solution) is a convenient quantity for examination of titration data in terms of assumed species, and for hydroxide complexes it is given by

$$
\bar{n}_{0}=\left(\left[H^{+}\right]-\left[\mathrm{OH}^{-}\right]-m_{H}\right) / m_{M}
$$

where the bracketed terms are actual ion molalities and $m_{H}$ and $m_{M}$ are total or stoichiometric molalities of acidity and metal ion present. [5] The numerator presents the missing hydroxide and $\bar{n}$ is equivalent to the average missing hydroxide per metal ion in solution. Typically the metal ion $\mathrm{M}^{\mathrm{z}+}$ hydrolyzes according to the equilibria

$$
x M^{2+}+y H_{2} \mathrm{O}=M_{x}(O H)_{y}^{(x-y)+}+y H^{*}
$$

with the corresponding formation quotients, $Q_{x, y}$, and $\bar{n}_{\text {calc }}$ where

$$
\bar{n}_{\text {calc }}=\left(\sum y Q_{x, y}\left[M^{z+}\right]^{x} /\left[H^{+}\right]^{y}\right) / m_{M}
$$

and $Q_{x, y}$ is derived by least squares analysis in which the free metal ion concentration is obtained by iteration of material balance equations. Also for a simple ionization of a weak acid

$$
\bar{n}_{\text {calc }}=Q /\left(\left[H^{+}\right]+Q\right)
$$

Software has been in routine use at ORNL by which the errors assigned to seventeen observables for solution make-up, temperature, volume of titrant, potential, etc., are propagated to $\bar{n}_{0}$ for weighting in least-squares analyses.

\section{RESULTS AND DISCUSSION}

\section{Acid-Base Equilibria}

Figure 2 shows results from EMF studies to $300^{\circ} \mathrm{C}$ for fifteen ionization reactions with a complete listing in Table 1 for weak acids and bases; this provides the most accurate data-base for any class of reactions in water at high temperatures. [6,7] The new results for organic acids, also listed in Table 1, are consistent with the trends shown in Figure 2 but sometimes results are limited to lower temperatures because of thermal instability. The curvature of the $\log \mathrm{K}$ vs $1 / \mathrm{T}$ plots is similar for all the reactions and when any one reaction is subtracted from the other, much simpler behavior is observed (i.e., the reaction is written in the all-cation or all-anion form (e.g., $\mathrm{NH}_{3}+\mathrm{H}^{+}=\mathrm{NH}_{4}{ }^{+}$, or $\mathrm{H}_{3} \mathrm{PO}_{4}+\mathrm{OH}^{-}=\mathrm{H}_{2} \mathrm{PO}_{4}^{-}+\mathrm{H}_{2} \mathrm{O}$ ). This form is also called "isocoulombic" (Lindsay, 1980) and provides a powerful means for extrapolation or interpretation of equilibrium 
and provides a powerful means for extrapolation or interpretation of equilibrium constants. [28] In addition, the potentiometric method provides data on salt effects (and therefore activity coefficients) that is not possible with the conductance approach, for example. The thermodynamics of these reactions have been discussed in some detail. $[6,7]$ The reactions are $\Delta S$ driven and the $\Delta S^{\circ}, \Delta V^{\circ}$, and $\Delta C p^{\circ}$ have divergences at the critical conditions indicative of involvement of large numbers of solvent molecules (or alternatively electrostriction of an infinitely compressible solvent). Some simplification has been observed when the density is held constant, i.e., ( $\partial$ log $\mathrm{K} / \partial \log \rho)_{\mathrm{T}}$ is nearly constant and varies little with temperature. $[6,19]$.

Table 1. Acid/Base Reactions Studied by Hydrogen-Electrode (or Glass Electrode) Potentiometry at ORNL.

\begin{tabular}{|c|c|c|c|c|}
\hline $\begin{array}{l}\text { Weak Acid on Base } \\
\left(K_{1}, \ldots K_{n}\right)^{\mathrm{a}}\end{array}$ & $T\left({ }^{\circ} \mathrm{C}\right)$ & I (medium) & Reference & \\
\hline \multirow[t]{4}{*}{$\mathrm{H}_{2} \mathrm{O}$} & $50-292$ & Im KCl & Mesmer, et al. (1970) & [3] \\
\hline & $0-300$ & $0-3 \mathrm{~m} \mathrm{KCl}$ & Sweeton, et al. (1974) & [ 8] \\
\hline & $25-295$ & $0-3 \mathrm{~m} \mathrm{NaCl}$ & Busey, Mesmer (1976) & [9] \\
\hline & $25-250$ & $0-7 \mathrm{~m} \mathrm{NaTr}{ }^{\mathrm{b}}$ & Palmer, Drummond (1988) & [10] \\
\hline $\mathrm{D}_{2} \mathrm{O}$ & $50-300$ & $0.2 \mathrm{~m} \mathrm{KCl}$ & Mesmer, Herting (1978) & [11] \\
\hline $\mathrm{H}_{3}^{2} \mathrm{PO}_{4} \mathrm{~K}_{1}, \mathrm{~K}_{2}, \mathrm{~K}_{3}^{\mathrm{c}}$ & $50-300$ & $0-1 \mathrm{~m} \mathrm{KCl}$ & Mesmer, Baes (1974) & [12] \\
\hline $\mathrm{D}_{2} \mathrm{PO}_{4}$ (base form) & $50-300$ & $0-.2 \mathrm{~m} \mathrm{KCl}$ & Mesmer, Herting (1978) & [11] \\
\hline $\mathrm{NH}_{3}$ (aq) (base form) & $50-295$ & $0-3 \mathrm{~m} \mathrm{KCl}$ & Hitch, Mesmer (1976) & [13] \\
\hline Cyclohexylamine $^{c}$ & $50-295$ & $0-0.1 \mathrm{KCl}$ & Mesmer, Hitch (1977) & [14] \\
\hline Morpholine $^{c}$ & $50-295$ & $0-.1 \mathrm{~m} \mathrm{KCl}$ & Mesmer, Hitch (1977) & [14] \\
\hline $\mathrm{CO}_{2}(\mathrm{aq})$ & $50-300$ & $0-5 \mathrm{~m} \mathrm{NaCl}$ & Patterson, et al. (1982) & [15] \\
\hline $\mathrm{HCO}_{3}^{-}$ & $50-250$ & $0-5 \mathrm{~m} \mathrm{NaCl}$ & Patterson, et al. (1984) & {$[16]$} \\
\hline Tris & $5-200$ & $0-5 \mathrm{~m} \mathrm{NaCl}$ & Palmer, Wesolowski (1987) & [17] \\
\hline BisTris & $5-125$ & $0-5 \mathrm{~m} \mathrm{NaCl}$ & Wesolowski, Palmer (1989) & [18] \\
\hline \multirow{2}{*}{$\mathrm{CH}_{3} \mathrm{COOH}$} & $50-300$ & $0-5 \mathrm{~m} \mathrm{NaCl}$ & Mesmer, et al. (1989) & [19] \\
\hline & $25-250$ & $0-5 \mathrm{~m} \mathrm{NaTr}$ & Palmer, Bell (unpublished) & \\
\hline $\mathrm{HSO}_{4}^{\circ}$ & $50-250$ & $0-5 \mathrm{~m} \mathrm{NaCl}$ & Dickson, et al. (1990) & [20] \\
\hline Oxalic & $0-175$ & $0-5 \mathrm{~m} \mathrm{NaCl}$ & Kettler, et al. (1991) & [21] \\
\hline Malonic acid $\left(\mathrm{K}_{1}, \mathrm{~K}_{2}\right.$ & $0-100$ & $0-5 \mathrm{~m} \mathrm{NaCl}$ & Kettler, et al. (1992) & [22] \\
\hline $\mathrm{HCOOH}$ (formic acid) & $25-200$ & $0-5 \mathrm{~m} \mathrm{NaCl}$ & Bell, et al. (1993) & [23] \\
\hline $\mathrm{C}_{6} \mathrm{H}_{5} \mathrm{COOH}$ (benzoic acid) & $5-250$ & $0-5 \mathrm{~m} \mathrm{NaCl}$ & Kettler, et al. (1994a) & [24] \\
\hline Succinic acid $\left(K_{1}, K_{2}\right)$ & $0-250$ & $0-5 \mathrm{~m} \mathrm{NaCl}$ & Kettler, et al. (1994b) & [25] \\
\hline d-Galacturonic acid & $25-100$ & $0-1 \mathrm{~m} \mathrm{NaCl}$ & Narkhede, et al. (1994) & [26] \\
\hline
\end{tabular}

\footnotetext{
${ }^{a}$ Stepwise dissociation constants. ${ }^{b} \mathrm{NaTr}=$ sodium trifluoromethanesulfonte. ${ }^{\circ}$ Actual reactions studied were in the "base" form $\mathrm{H}_{3} \mathrm{PO}_{4}+\mathrm{OH}^{-}=\mathrm{H}_{2} \mathrm{PO}_{4}{ }^{\circ}+\mathrm{H}_{2} \mathrm{O}$ or $\mathrm{NH}_{3}(\mathrm{aq})+$ $\mathrm{H}_{2} \mathrm{O}=\mathrm{NH}_{4}^{+}+\mathrm{OH}^{-}$. ${ }^{\text {d tris }}$ \{hydroxymethyl aminomethane\}.
}

\section{Metal Ion Hydrolysis}

Studies of the hydrolysis of metal ions according to the equilibria in Equation (5) at elevated temperatures using concentration cells at ORNL are listed in Table 2. Results for the first hydrolysis reaction of $\mathrm{Al}^{3+}$, i.e., $(\mathrm{x}, \mathrm{y})=(1,1)$ in dilute solutions by Palmer and Wesolowski are presented in Figure 3 [at $\mathrm{I}=0.096 \mathrm{~mol} \cdot \mathrm{kg}^{-1}$ at $25^{\circ}$ and $75^{\circ} \mathrm{C}$. [33] Measurements were made over the range 25 to $125^{\circ} \mathrm{C}$ at ionic strengths $0.1,0.3,1.0$, and $5.0 \mathrm{~mol} \cdot \mathrm{kg}^{-1}$ with $\mathrm{NaCl}$ as the supporting electrolyte. The maximum degree of 
a)

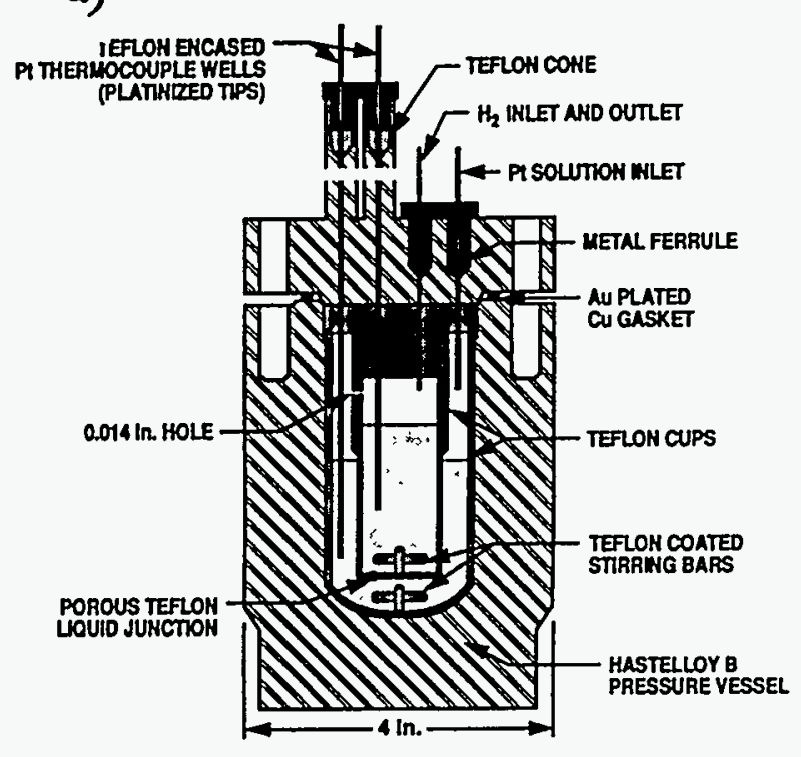

b)

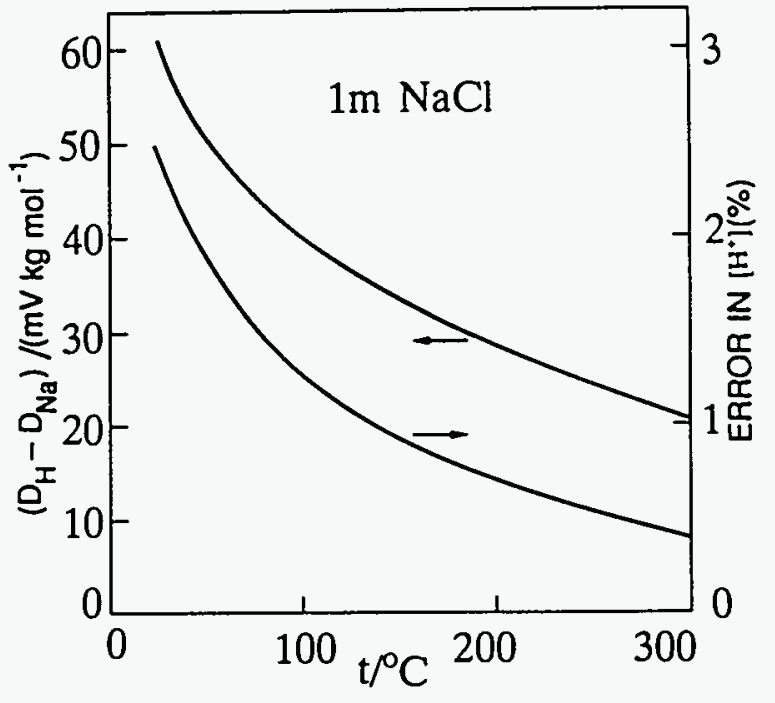

Figure 1. (a) Schematic drawing of the ORNL hydrogen electrode concentration cell (modified from ref. 3). (b) Liquid junction contribution to $\Delta E$ for cells where $1 \%$ of the $\mathrm{Na}^{+}$is replaced by $\mathrm{H}^{+}$in the presence of $1 \mathrm{~m} \mathrm{NaCl}$; the right ordinate is the error in $\mathrm{H}^{+}$concentration from neglecting $\mathrm{E}_{\mathrm{LJ}}$. [1]

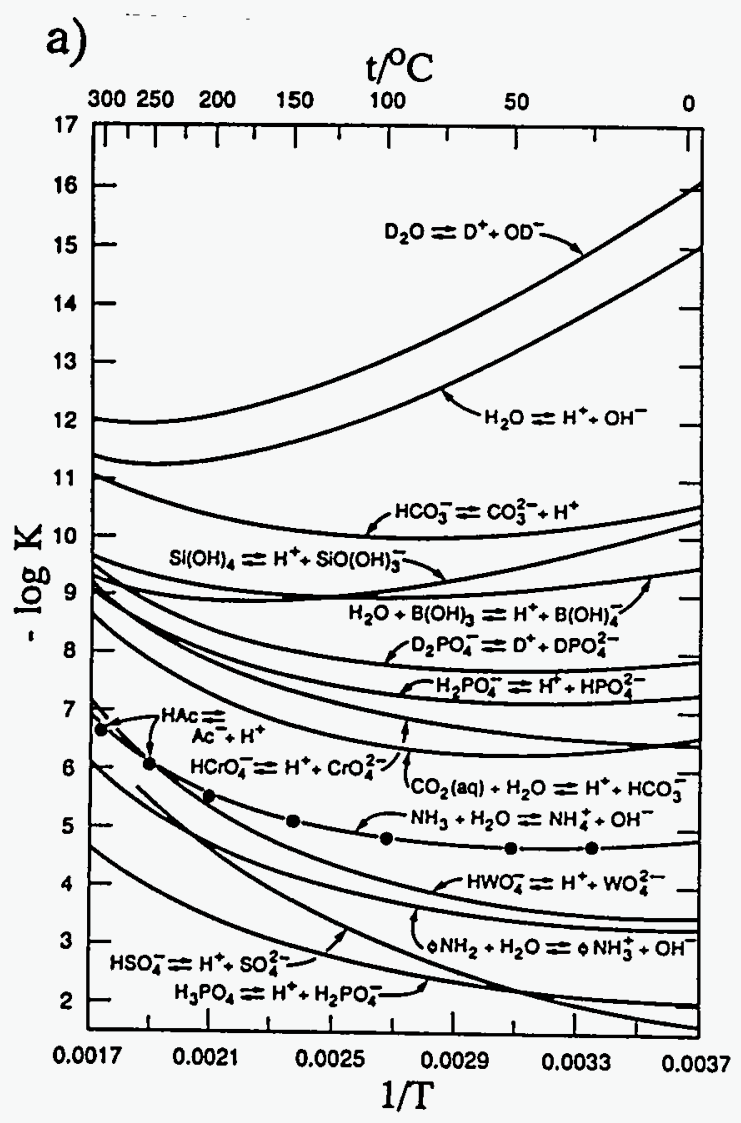

b)

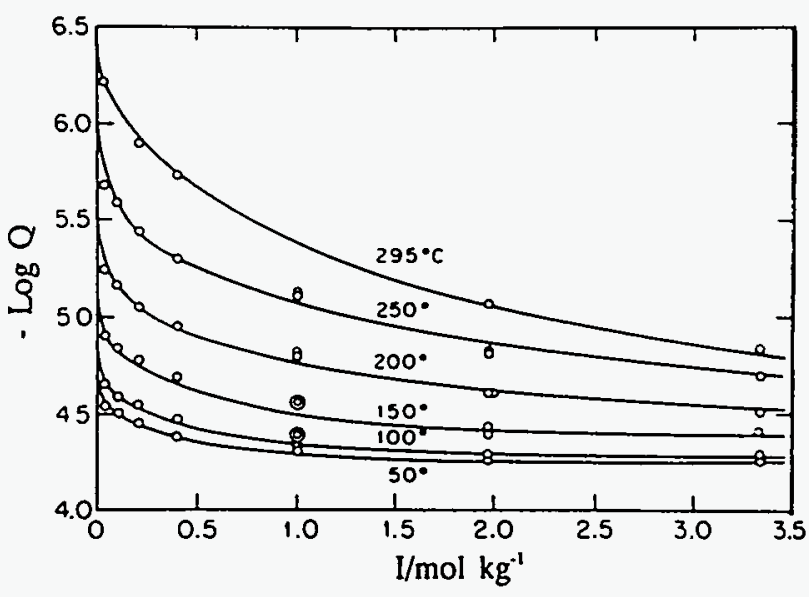

Figure 2. (a) Logarithm of the dissociation constants for weak acids and bases to $300^{\circ} \mathrm{C}$. [6] (b) Logarithm of the dissociation quotient for $\mathrm{NH}_{3}(\mathrm{aq})$ to $295^{\circ} \mathrm{C}$ in $\mathrm{KCl}$ media. [13] 
hydrolysis observed was ca. $30 \%$ at concentrations $<6 \times 10^{-4}$ mol. $\mathrm{kg}^{-1}$. The log $\mathrm{K}_{1,1}$ varies from $-4.95 \pm 0.03$ at $25^{\circ}$ to $-1.36 \pm 0.06$ at $200^{\circ} \mathrm{C}$ and is linear in $1 / \mathrm{T}$.

Table 2. Metal Ion Hydrolysis Reactions Studied by

Hydrogen Electrode (or Glass Electrode) Potentiometry at ORNL

\begin{tabular}{|c|c|c|c|c|c|}
\hline $\begin{array}{l}\text { Hydrolysis } \\
\text { Products }^{\mathrm{a}}\end{array}$ & $\begin{array}{l}(x, y) \\
\text { determined }\end{array}$ & $\mathrm{T}\left({ }^{\circ} \mathrm{C}\right)$ & I (medium) & Reference & \\
\hline \multirow[t]{2}{*}{$\left.\left(\mathrm{UO}_{2}\right)_{x} \mathrm{OH}\right)_{y}^{(2 x-y) t}$} & $(1,1)(2,2)(3,5)$ & 94.4 & $0.5 \mathrm{~m} \mathrm{KCl}$ & Baes, Meyer (1962) & [28] \\
\hline & $\begin{array}{c}(2,2)(3,5)(3,7) \\
(3,8)(3,10)\end{array}$ & $25-225$ & $0.1 \mathrm{~m}$ TMATr $^{\mathrm{b}}$ & $\begin{array}{l}\text { Nguyen-Trung, et al } \\
(1993)^{c}\end{array}$ & [29] \\
\hline $\operatorname{Th}_{x}(\mathrm{OH})_{y}{ }^{(4 x-y)+}$ & $\begin{array}{c}(1,1)(1,2)(2,2) \\
(4,8)(6,15)\end{array}$ & 0,95 & $1.0 \mathrm{~m} \mathrm{NaCl}$ & Baes, et al (1965) & [30] \\
\hline $\mathrm{Be}_{x}(\mathrm{OH})_{y}^{(2 x-y) t}$ & $(2,1)(3,3)(5,7)$ & $0-60$ & $1.0 \mathrm{~m} \mathrm{NaCl}$ & Mesmer, Baes (1967) & [31] \\
\hline \multirow[t]{2}{*}{$\mathrm{Al}_{x}(\mathrm{OH})_{y}^{(3 x-y)+}$} & $\begin{array}{l}(2,2)(3,4) \\
(14,34)\end{array}$ & $62-150$ & $1.0 \mathrm{~m} \mathrm{KCl}$ & Mesmer, Baes (1971) & [32] \\
\hline & $(1,1)$ & $25-125$ & $0-5 \mathrm{~m} \mathrm{NaCl}$ & $\begin{array}{l}\text { Palmer, Wesolowski } \\
\text { (1993) }\end{array}$ & [33] \\
\hline$B_{x}(O H)^{y}{ }_{3 x+y}$ & $\begin{array}{l}(1,1)(2,1)(3,1) \\
(4,2)\end{array}$ & $60-290$ & $0-1 \mathrm{~m} \mathrm{KCl}$ & Mesmer, et al (1972) & [34] \\
\hline $\mathrm{Si}_{x}(\mathrm{OH})^{\mathrm{y}-{ }_{4 x+y}}$ & $\begin{array}{l}(1,1)(1,2)(3,1) \\
(4,2)(5,2)(6,3)\end{array}$ & $60-290$ & $1.0 \mathrm{~m} \mathrm{NaCl}$ & $\begin{array}{l}\text { Busey, Mesmer } \\
\text { (1971) }\end{array}$ & [27] \\
\hline $\mathrm{Ca}(\mathrm{OH})^{+}$ & $(1,1)$ & $50-250$ & $1.0 \mathrm{~m} \mathrm{KCl}$ & Mesmer (unpubl) & \\
\hline $\mathrm{H}_{y}\left(\mathrm{WO}_{4}\right)_{x}{ }^{6}$ & $\begin{array}{c}(1,1)(1,2)(6,7) \\
(6,10)(12,18)\end{array}$ & $95-295$ & $0-5 \mathrm{~m} \mathrm{NaCl}$ & $\begin{array}{l}\text { Wesolowski, et al } \\
\text { (1984) }\end{array}$ & [35] \\
\hline $\mathrm{H}_{y}\left(\mathrm{CrO}_{4}\right)_{x}^{(y-2 x)+}$ & $(1,1)(1,2)(2,2)$ & $25-175$ & $0-5 \mathrm{~m} \mathrm{NaCl}$ & Palmer, et al (1987) & [36] \\
\hline & $(1$, & $0-250$ & $0-5 \mathrm{~m} \mathrm{NaCl}$ & $\begin{array}{l}\text { Wesolowski, Palmer } \\
\text { (1994) }\end{array}$ & [37] \\
\hline
\end{tabular}

a Hydrolysis in terms of $\mathrm{H}^{+}$except for $\mathrm{B}(\mathrm{OH})_{3}, \mathrm{Si}(\mathrm{OH})_{4}$, and $\mathrm{Ca}^{2+}$ which are written in terms of $\mathrm{OH}^{-}$to form $\mathrm{M}_{\mathrm{x}}(\mathrm{OH})_{\mathrm{x}}^{\left({ }^{x}-y\right)+}$ species; the unhydrolyzed metal ion is the reactant ion except for $\mathrm{B}(\mathrm{OH})_{3}, \mathrm{Si}(\mathrm{OH})_{4}, \mathrm{WO}_{4}{ }^{2-}$, and $\mathrm{CrO}_{4}{ }^{2-}$ for which the latter species are the reactants.

${ }^{\mathrm{b}} \mathrm{TMATr}=$ (Tetramethylammonium(trifluoromethanesulfonate).

${ }^{\circ}$ Coupled with Raman spectroscopy.

\section{Metal Complexation}

Studies using concentration cells for measurements of the degree of metal complexation at ORNL are listed in Table 3. Figure 4(a) is an example that demonstrates the power of this EMF approach for studies of complexation by the anion of a weak acid, acetic acid. This study of ferrous acetate complexes was conducted by Palmer and Drummond in sodium trifluoromethanesulfonate as the non-complexing supporting electrolyte. [30] Results are presented in terms of the observed ligand number $\bar{n}_{0}$, the average number of acetates bound per metal ion in solution. Ligand numbers up to about 1.5 to 2.5 were attained; from the systematic variation of solution composition the equilibrium quotients for reactions involving the species $\mathrm{Fe}\left(\mathrm{CH}_{3} \mathrm{CO}_{2}\right)_{n}^{(2-n)+}$ with $(n=1,2,3)$ were determined and summarized in Table 3 . Similar studies have been made for $\mathrm{Zn}^{2+}$ and $\mathrm{Al}^{3+}$. [39,40] Ferrous chloride complexes were studied by Palmer and Hyde [41] in the presence of acetate by the competitive ligand approach, and results for the first complex are compared in Figure $4(\mathrm{~b})$ for $\mathrm{FeOH}+\mathrm{Fe}\left(\mathrm{CH}_{3} \mathrm{CO}_{2}\right)^{+}$ 

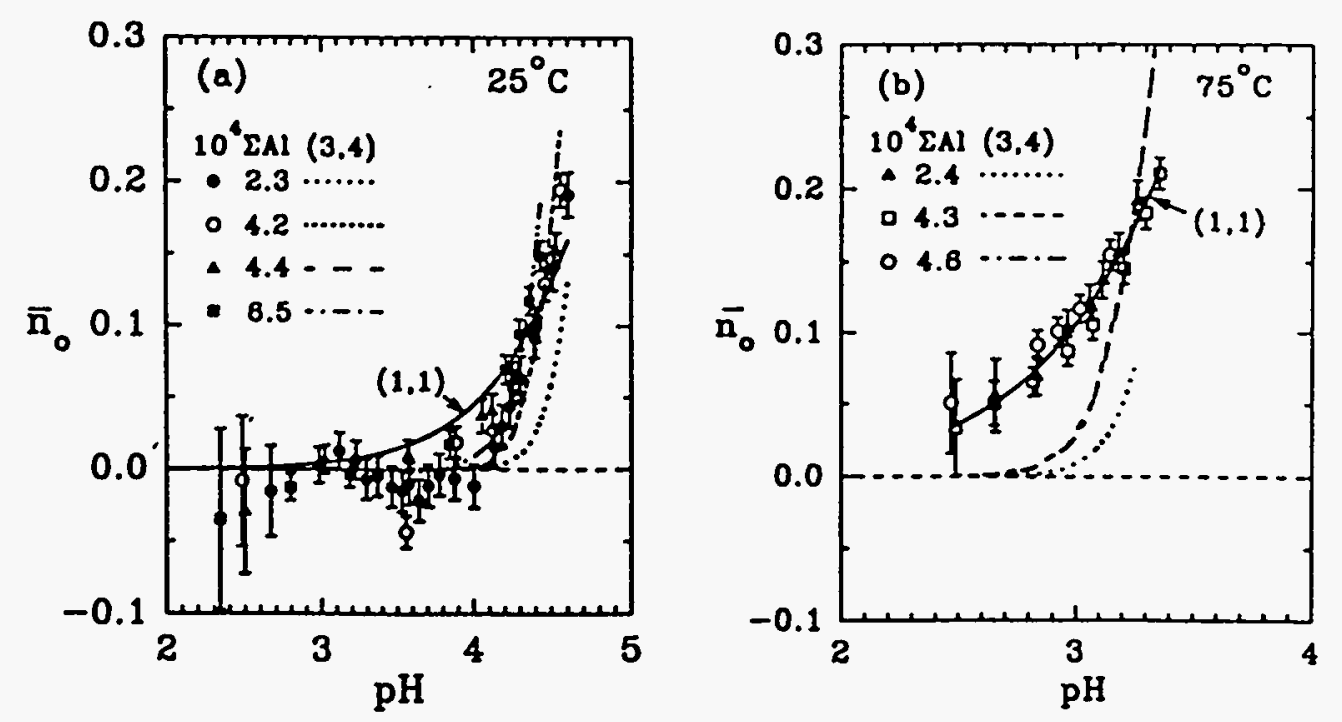

Figure 3. Titration curves showing $\bar{n}_{0}$ vs $\mathrm{pH}$ at (a) $25^{\circ}$ and (b) $75^{\circ} \mathrm{C}$ at $\mathrm{I}=0.096$ mol. $\mathrm{kg}^{-1}$. [33] (Temperatures range $50^{\circ}-250^{\circ} \mathrm{C}$ at $50^{\circ} \mathrm{C}$ intervals with $295^{\circ} \mathrm{C}$ at the top).

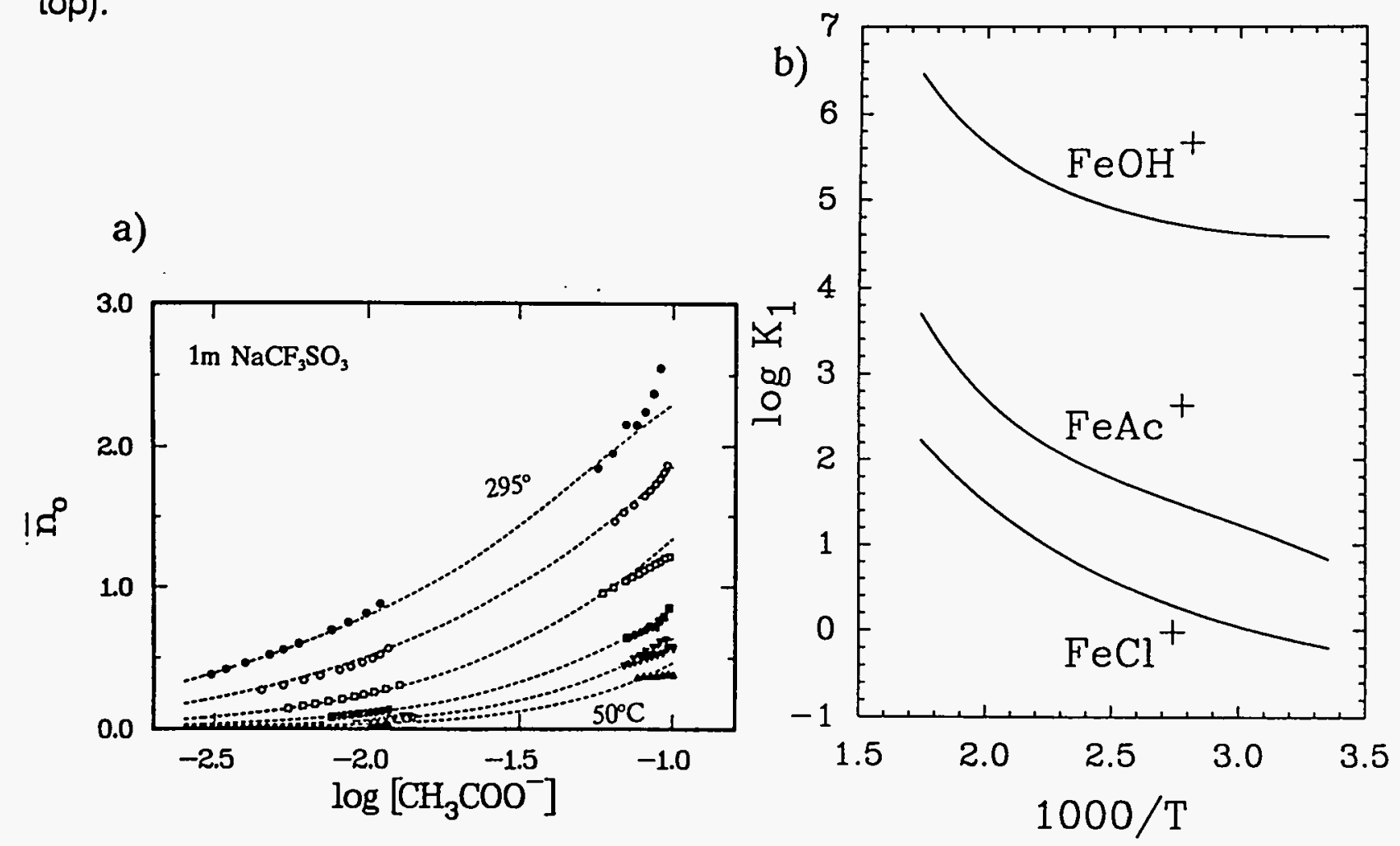

Figure 4. (a) Observed and calculated ligand numbers for $\mathrm{Fe}(\mathrm{AC})_{n}{ }^{(2-n)+}$ complexation. [38] (b) Association constants for ferrous complexes of acetate, chloride, and hydroxides. [7] 
and $\mathrm{FeCl}^{+}$. [7] All show the similar temperature dependencies, the trend expected for charge-neutralization reactions.

Table 3. Metal Complexation Studies Using Potentiometry at ORNL

\begin{tabular}{|c|c|c|c|c|}
\hline $\begin{array}{l}\text { Reaction } \\
M^{2+}+y X^{-}=M_{y}^{(3-y)+}\end{array}$ & $\mathrm{T}\left({ }^{\circ} \mathrm{C}\right)$ & I (medium) & Reference & \\
\hline $\begin{array}{l}\mathrm{Fe}\left(\mathrm{CH}_{3} \mathrm{COO}\right)_{y}^{2-y} ; y=1,2,3 \\
\mathrm{Zn}\left(\mathrm{CH}_{3} \mathrm{COO}\right)_{y^{2-y} ; y=1,2,3} ; y=1,2,3 \\
\mathrm{Al}\left(\mathrm{CH}_{3} \mathrm{COOO}\right)_{y}^{y-y} ; y=1,2 \\
\mathrm{FeCl}^{+} \\
\mathrm{CdCl}_{y}^{2-y} ; y=1,2,3\end{array}$ & $\begin{array}{c}50-295 \\
50-295 \\
25-150 \\
125-295 \\
25-250\end{array}$ & $\begin{array}{l}0-1 \mathrm{~m} \mathrm{NaTr} r^{\mathrm{a}} \\
0-1 \mathrm{~m} \mathrm{NaTr} r^{\mathrm{a}} \\
0-1 \mathrm{~m} \mathrm{NaCl} \\
1 \mathrm{~m} \mathrm{NaTr} r^{\mathrm{a}} \\
0-5 \mathrm{~m} \mathrm{NaTr}{ }^{\mathrm{a}}\end{array}$ & $\begin{array}{l}\text { Palmer,Drummond (1988) } \\
\text { Giordano,Drummond (1991) } \\
\text { Palmer,Bell (1994) } \\
\text { Palmer, Hyde (1993) } \\
\text { Palmer,et al (unpublished) }\end{array}$ & $\begin{array}{l}{[38]} \\
{[39]} \\
{[40]} \\
{[41]}\end{array}$ \\
\hline
\end{tabular}

${ }^{a} \mathrm{NaTr}=$ sodium trifluoromethanesulfone

\section{ACKNOWLEDGEMENT}

The authors gratefully acknowledge all those who participated in potentiometry at ORNL. This work is sponsored by the Division of Chemical Sciences (R.E.M. and D.A.P) and the Division of Geosciences (D.J.W.), Office of Basic Energy Sciences, U.S. Department of Energy, under contract DE-AC05$840 R 21400$ with Martin Marietta Energy Systems, Inc.

\section{REFERENCES}

1. Mesmer, R. E. and H. F. Holmes. 1992. pH, definition and measurement at high temperatures. J. Solution Chem. 21:725.

2. Lietzke, M. H. 1973. Reference electrodes. in High temperature high pressure electrochemistry in aqueous solution. Surrey England, NACE, p. 317.

3. Mesmer, R. E., C. F. Baes, Jr., and F. W. Sweeton. 1970. Acidity measurements at elevated temperatures. IV. Apparent dissociation of water in $1 \mathrm{~m}$ potassium chloride up to $295^{\circ} \mathrm{C}$. J. Phys. Chem. 74:1937.

4. Sweeton, F. H., R. E. Mesmer, and C. F. Baes, Jr. 1973. A high temperature flowing EMF cell. J. Phys. E. Instrum. 6:165.

5. Baes, C. F., Jr. and R. E. Mesmer. 1976. The Hydrolysis of Cations. New York: John Wiley and Sons. New York, p. 489.

6. Mesmer, R. E., W. L. Marshall, D. A. Palmer, J. M. Simonson, and H. F. Holmes. Thermodynamics of aqueous association and ionization reactions at high temperatures and pressures. J. Solution Chem. 17:699.

7. Mesmer, R. E., D. A. Palmer, and J. M. Simonson. 1991. Ion association at high temperatures and pressures. in Activity Coefficients in Electrolyte Solutions. K. S. Pitzer, ed., CRC Press.

8. Sweeton, F. H., R. E. Mesmer, and C. F. Baes, Jr. 1974. Acidity measurements at elevated temperatures. VII. Dissociation of water. J. Solution Chem. 3:191.

9. Busey, R. H. and R. E. Mesmer. 1976. The ionization of water in $\mathrm{NaCl}$ media to $300^{\circ} \mathrm{C}$. J. Solution Chem. $5: 11 ; 1978$. Thermodynamics quantities for the ionization of water in sodium chloride media to $300^{\circ} \mathrm{C}$. J. Chem. Eng. Data 33:175.

10. Palmer, D. A. and S. E. Drummond. 1988. The molal dissociation quotients of water in sodium trifluoromethanesulfonate solutions to high temperatures. J. Solution Chem. 17:153.

11. Mesmer, R. E. and D. L. Herting. 1978. Thermodynamics of ionization of $\mathrm{D}_{2} \mathrm{O}$ and $\mathrm{D}_{2} \mathrm{PO}_{4}$. J. Solution Chem. 7:901.

12. Mesmer, R. E. and C. F. Baes, Jr. 1974 Phosphoric acid dissociation equilibria in aqueous solutions to $300^{\circ} \mathrm{C}$. J. Solution Chem. 3:307.

13. Hitch, B. F. and R. E. Mesmer. 1976. The ionization of aqueous ammonia to $300^{\circ} \mathrm{C}$ in $\mathrm{KCl}$ media. $\mathrm{J}$. Solution Chem. 5:667.

14. Mesmer, R. E. and B. F. Hitch. 1977. Base strength of amines at high temperatures. Ionization of cyclohexylamine and morpholine. J. Solution Chem. 6:251.

15. Patterson, C. S., G. Slocum, R. H. Busey, and R. E. Mesmer. 1982. Carbonate equilibria in hydrothermal solutions: First ionization of carbonic acid in $\mathrm{NaCl}$ media to $300^{\circ} \mathrm{C}$. Geochim. Cosmochim. Acta 44:1653. 
16. Patterson, C. S., R. H. Busey, and R. E. Mesmer. 1984. Second ionization constant of carbonic acid in $\mathrm{NaCl}$ media to $250^{\circ} \mathrm{C}$. J. Solution Chem. 13:647.

17. Palmer, D. A. and D. J. Wesolowski. 1987. The acid association quotient of tris-(hydroxymethyl) amminomethane in aqueous $\mathrm{NaCl}$ Media to $200^{\circ} \mathrm{C}$. J. Solution Chem. 16:571.

18. Wesolowski, D. J. and D. A. Palmer. 1989. Acid association quotients of bis-tris in aqueous sodium chloride media to $125^{\circ} \mathrm{C}$. J. Solution Chem. 18:545.

19. Mesmer, R. E., C. S. Patterson, R. H. Busey, and H. F. Holmes. 1989. Ionization of acetic acid in $\mathrm{NaCl}(\mathrm{aq})$ media: A Potentiometric study to $573 \mathrm{~K}$ and 130 bars. J. Phys. Chem. 93:7483.

20. Dickson, A. G., D. J. Wesolowski, D. A. Palmer, and R. E. Mesmer. 1990. A potentiometric determination of the dissociation constants $\mathrm{HSO}_{4}$ in aqueous sodium chloride solutions to $250^{\circ}$ C. J. Phys. Chem. 94:7978.

21. Kettler, R. M., D. A. Palmer, and D. J. Wesolowski. 1991. Dissociation constants of oxalic acid in aqueous sodium chloride media to $175^{\circ} \mathrm{C}$. J. Solution Chem. 20:905.

22. Kettler, R. M., D. A. Palmer, and D. J. Wesolowski. 1992. Dissociation quotients of malonic acid in aqueous sodium chloride media to $100^{\circ} \mathrm{C}$. J. Solutions Chem. 21:883.

23. Bell, J.L.S., D. J. Wesolowski, and D. A. Palmer. 1993. The dissociation quotient of formic acid in sodium chloride solutions to $200^{\circ} \mathrm{C}$. J. Solution Chem. 22:125.

24. Kettler, R. M., D. J. Wesolowski, and D. A. Palmer. 1994. The dissociation quotient of benzoic acid in aqueous sodium chloride media to $250^{\circ} \mathrm{C}$. J. Solution Chem.

25. Kettler, R. M., D. A. Palmer, and D. J. Wesolowski. 1994. Dissociation quotients of succinic acid in aqueous sodium chloride media to $250^{\circ} \mathrm{C}$. J. Solution Chem.

26. Narkhede, M. R., D. A. Palmer, and C. Nguyen-Trung. 1994. Dissociation quotients of D-galacturonic acid to 1 molal ionic strength and $100^{\circ} \mathrm{C}$. J. Solution Chem.

27. Busey, R. H. and R. E. Mesmer. 1977. Ionization equilibria of silicic acid and polysilicate formation in aqueous sodium chloride solutions to $300^{\circ} \mathrm{C}$. Inorg. Chem. 16:244.

28. Baes, C. F., Jr. and N. J. Meyer. 1962. Acidity measurements at elevated temperatures I. Uranium (VI) hydrolysis at $25^{\circ} \mathrm{C}$ to $94^{\circ} \mathrm{C}$. Inorg. Chem. 1:780.

29. Nguyen-Trung, C, D. A. Palmer, and G. M. Begun. 1993. Hydrolysis of the uranyl ion in hydrothermal solutions by Raman spectroscopy and potentiometry up to $225^{\circ} \mathrm{C}, 50 \mathrm{MPa}$. Proceedings 4th Int. Symp. on Hydrothermal Reactions. A.A. Balkema, p. 163.

30. Baes, C. F., Jr., N. J. Meyer, and C. E. Roberts. 1965. The hydrolysis of thorium (IV) at 0 to $95^{\circ} \mathrm{C}$. Inorg. Chem. 4:518.

31. Mesmer, R. E. and C. F. Baes, Jr. 1967. The hyrolysis of Be(II) in $1 \mathrm{~m} \mathrm{NaCl}$. Inorg. Chem. 6:1951.

32. Mesmer, R. E. and C. F. Baes, Jr. 1971. Acidity measurements at elevated temperatures. V. Aluminum ion hydrolysis. Inorg. Chem. 10:2290.

33. Palmer, D. A. and D. J. Wesolowski. 1993. Aluminum speciation and equilibria in aqueous solution: III. Potentiometric determination of the first hydrolysis constant of aluminum (III) in sodium chloride solutions to $125^{\circ} \mathrm{C}$. Geochim. Cosmochim. Acta. 57:2929.

34. Mesmer, R. E., C. F. Baes, Jr., and F. H. Sweeton. 1972. Acidity measurements at elevated temperatures. VI. Boric acid equilibria. Inorg. Chem. 11:537.

35. Wesolowski, D. J., S. E. Drummond, R. E. Mesmer, and H. Ohmoto. 1984. Hydrolysis of tungsten (VI) in aqueous sodium chloride solutions to $300^{\circ} \mathrm{C}$. Inorg. Chem. 23:1120.

36. Palmer, D. A., D. J. Wesolowski, and R. E. Mesmer. 1987. A potentiometric investigation of the hydrolysis of chromate (VI) ion in $\mathrm{NaCl}$ media to $200^{\circ} \mathrm{C}$. J. Solution Chem. 16:443.

37. Wesolowski, D. J. and D. A. Palmer. 1994. Potentiometric study of the hydrolysis of $\mathrm{Mg}^{2+}$ in 0.1 molal to 5.0 molal $\mathrm{NaCl}$ brines from 25 to $250^{\circ} \mathrm{C}$. J. Solution Chem.

38. Palmer, D. A. and S. E. Drummond. 1988. Potentiometric determination of the molal formation constants of ferrous acetate complexes in aqueous solutions to high temperatures. J. Phys. Chem. 92:6795.

39. Giordano, T. H. and S. E. Drummond. 1991. The potentiometric determination of stability constants of zinc acetate complexes in aqueous solutions to $295^{\circ} \mathrm{C}$. Geochim. Cosmochim. Acta 55:2401.

40. Palmer, D. A. and J.L.S. Bell. 1994. Aluminum speciation and equilibria in aqueous solution. IV. A potentiometric study of aluminum acetate complexation in acidic $\mathrm{NaCl}$ brines to $150^{\circ} \mathrm{C}$. Geochim. Cosmochim. Acta. 58:651.

41. Palmer, D. A. and K. E. Hyde. 1993. An experimental determination of ferrous chloride and acetate complexation in aqueous solutions to $300^{\circ} \mathrm{C}$. Geochim. Cosmochim. Acta. 57:393. 